\title{
PROFESSOR CROSSKEY AND THE BROODING OMNIPRESENCE OF ERIE-TOMPKINS
}

\author{
Charles E. Ctarki
}

$\mathrm{P}$ ROFESSOR CROSSKEY'S NEW BOOK on the Constitution ${ }^{1}$ is an exciting work. It is exciting for a reason as unique as it is admirable with respect to this type of book, namely, the intellectual punch it delivers. We are accustomed to stately works ringing the now accepted changes of reverence to the Constitution in its modern guise as fashioming a union of diverse, almost warring, states. Occasionally-so much so as now to be almost a rarity-we do find specific criticism of the creaking governmental structure which results and some despairing hope for change in the direction of modern efficiency. ${ }^{2}$ But this opus is something quite different and beyond our experience. For it is a new history, the fruit of nearly two decades of patient research, which presents the direct challenge that the original plan and intent of the Constitution was the creation of a simply conceived national government. A possibihty of simplicity in place of infimite complexity, of effective functional action instead of near-paralysis amid competing sovereignties, is surely alluring. And with proof so detailed and withal so persuasive as here afforded, we must hail this as a major scholastic effort of our times.

The feat of scholarship is perhaps the more remarkable when we coune to see that the author's main thesis rests upon an utterly simple approach: interpreting the letter of the great document primarily in accordance with eighteenth century views of language, form, and substance. With propriety he calls the resulting panorama "A Unitary View of the National Governing Powers." Emerging fully as clear cut are his correlative and supporting theses. Of these, the two he singles out for the greatest stress are "The National Power over Commerce" and "The National Judicial

$\dagger$ Circuit Judge, United States Court of Appeals, Second Circuit.

${ }^{2}$ Crosskey, Politics and the Constitution in the History of the United States (1953) (hereafter cited only by part, chapter, or page).

2 The boldest of recent times appears to be Finletter, Can Representative Government Do the Job? (1945). See also Clark, The Dilemma of American Judges: Is Too Great "Trust for Salvation" Placed in Them? 35 A.B.A.J. 8, and other references given at 80, 81 (1949).

3 This is made the title heading of Part III, pp. 361-708.

4 Part I, pp. 15-292. 
Powers."' These, too, a reviewer may pinpoint to illustrate the author's method and approach.

First, as background we must note the infinite pains taken to recreate a vocabulary which appropriately mirrors the eighteenth century mind operating in the constitutional framework. Thus we have an extensive catalogue of all manner of usage in pre-convention days of the term "commerce," showing, indeed, its broad inclusiveness. The same process is employed as to the other terms of the constitutional grant over commerce; and the pre-constitution usage is supported by the contemporary discussions centering around the making of the Constitution and the notable debate which preceded its adoption in the states. This leads directly to the constitutional interpretation, in terms generally of strong governmental powers, which prevailed originally and which has suffered a gradual decline to the weaker governmental entity we now know.

It is against this tapestry, so fully displayed before the reader's eye, that the famous clauses undergo a revitalization of meaning and take on new dynamism. Consider the first power listed, that of the legislature, and the first general statement of its authority beyond the power to tax and to borrow money, to wit, the power "To regulate Commerce with foreigu Nations, and among the several States, and with the Indian Tribes." The nnddle phrase has suffered a debasement down to our modern concept of power over only "imterstate commerce," famous words of modern times, but unknown to the man of 1787 and dating apparently from the middle of the last century. Others of the constitutional words have also suffered sea-change by shrinkage: "among" becomes "between"; the states are now mere territorial subdivisions between which some physical movement has become visualized; and "commerce" itself has been narrowed to mean only a special kind of business enterprise. Hence the phrase now is reduced to permitting some limited control over this restricted form of enterprise only when it actually and visibly moves "from the territory of one of our states to that of another." But under our author's compelling exegesis the phrase comes to life as including all matters of trade or business activity had among or within the states all over the country, and supports and justifies the widest congressional supervision of the affairs of men considered as people of a single union. Thus, for example, we should not need to await the tedious and only partial accomplishment of the strongly urged uniform commercial acts-with a umform

${ }^{5}$ See particularly cc. XX, XXI, pp. 610-74; also Part IV, pp. 711-1046.

- U.S. Const. Art. 1, § 8, discussed pp. 17 et seq. 
law of divorce not even dared-to secure the benefits of free commerce subject to like law throughout the states. ${ }^{7}$ Instead, Congress is summoned, even in the dedication of the book, "to claim and exercise for the common good of the country the powers justly belonging to it under the Constitution,"8 including that of formulating just such commercial codes and general social laws as are here contemplated.

A similar demonstration leads to the conclusion-further discussed below-that the original constitutional intent was to create a single national judicial system, with the Supreme Court at the apex of all courts, state and federal. ${ }^{9}$ Briefer treatment sets forth the interrelationship with the Commerce Clause of other provisions of Article I, notably the Imports and Exports, Ex post facto, and Contracts Clauses. ${ }^{10}$

To do even partial justice to the demonstration, some brief reference must be made to certain other features of the supporting argument. Thus it is held that accepted rules of eighteenth century approach to state documents require recognition of the custom to state an intent as an inclusive generality, followed by an enumeration of details of an informative, but not exclusive, character. Hence the enumeration of the powers of Congress-now made the bulwark for the limiting interpretation of the Constitution-is held not to subtract just the specified powers from the states. Rather it is addressed primarily to a different dichotomy, that between legislative and executive powers in the one unitary goverumental system set up; the balance here inclined toward the legislature, an emphasis needed if the historic power of the royal prerogative was to be lessened and the dangerous weakness of the earlier Congress to be corrected. "Fmally to be dissected is the famous Tenth Amendment, reserving to the states or the people "The powers not delegated to the United States by the Constitution, nor prohibited by it to the States." solution is that made, among others, and again from an eighteenth century background, by no less a person than James Kent in a decision in New York in $1812,{ }^{13}$ to the effect that the powers not exclusively transferred to the United States or prohibited to the states may still be exercised by the latter, as well as by the people.

Even this inadequate summary shows how revolutionary this thesis is

' See particularly pp. 32, 37, 292.

- See note 5 supra.

s. v.

${ }^{10}$ Cc. X-XII, pp. 295-360.

11 C. XIII-XVII, pp. 363-562.

18 U.S. Const. Amend. 10, discussed in c. XXII, pp. 675-708.

1s Livingston v. Van Ingen, 9 Johns. (N.Y.) 507 (1812). 
to an age which is accustomed to see the states successfully fighting the national government on all stages, from control of precious national resources to exercise of taxing and regulatory powers in many forms and guises. Does the author adequately prove his case? Only an historian of quite a degree of sophistication can judge with finality and as to details. But for the ordinary reader and patriotic citizen, anxious for his government to exercise effective leadership in the global role now thrust upon it, Professor Crosskey surely proves enough to require a fresh approach in our constitutional thinking. For at the very least he does demonstrate beyond what seems to me the possibility of doubt (1) that an exceedingly powerful argument can be made for a widespread eighteenth century intent or desire for a stronger central government than we have now evolved, (2) that the constitutional language is much more apt to sustain such an intent than our juristic thought now concedes, (3) that considerable early thought, including Supreme Court decisions, so mterpreted the infant Constitution, and (4) that exigencies of political strife shaped and molded the great charter to its present form.

Although I suspect the contrary will be the case, the last of these points I have stressed ought not to come as a shock or even as a surprise to a generation accustomed to a realistic approach to law and legal actions. We know that contracts and legal documents generally may be variously interpreted against different backgrounds, particularly where new circumstances bring new problems not appreciated in the original bond. So even the words of a written Constitution may acquire quite a different significance as the years pass. And the reasons why the Jeffersonians, representing broadly the masses as against the propertied classes, should have feared the power of a strong government, should have demanded a Bill of Rights and all the rest, seem now but a natural commonplace of the time. That the states, in the vacuum of power which the struggle tended to create, should be the obvious, but rather unintended, beneficiaries is also but a natural, even if chance, result. But here the author has seemingly courted opposition by the truculence with which he presents his views and the virulence of his condemnation of the politicians. Madison's star has perhaps dimmed, simce his obvious changes of opinion to correspond with his politics do not evoke sympathy. But Jefferson is still a mighty force; condemnation of his actions even to the point of rehabilitating the Sedition Act was hardly necessary. It is likely to stimulate reactions such as those of one professorial reviewer who betrayed an einotional mvestment in the constitutional status quo curious to behold; he even suggested the 
unworthiness of a university press which would stoop to publish this original new work! $!^{14}$

In truth the author's combativeness here may appear surprising; for, except in some matters of degree, the difference in party spirit and program of the era is well accepted. ${ }^{15}$ But the author does carry it further than is customary. He has both Jefferson and Madison as early Nationalists who departed from the faith for reasons political, while Marshall is shown fighting merely a rear guard and constantly losing struggle, full of compromises, turns, and twists, to preserve a semblance of strength to the central government. So personal does he make this struggle and the motivations of the distinguished protagonists that many are likely to be turned away from his important thesis. Having known the author in all his forthrightness and obduracy from his student days, I can, I think, understand how his own conception of truth would not permit him to yield even the proverbial ell to the humanness of politicians. If the great $\mathrm{X}$ was that kind of petty heel, it must be so stated. Moreover, such a sense of personal involvement in long ago battles was doubtless necessary to sustain research so exhaustive for so nany years with so little of definite encouragement from any source except one's own imer strength of character. Actually of course politicians and statesmen are neither so admirable nor so despicable as contemporaries and posterity love to make them. They can and often do operate from motives far from sublime, even those which are petty and vengeful; in short they cannot avoid acting like human beings. And yet they do represent movements and trends which must cone to the fore, if not through one group of protagonists then through another. There is an inevitability about conflict and change in affairs governmental which we must accept and expect.

But nothing so pusillanimous-as this appeals to our author. Here is one person at least who is not inhibited by idol worship in an area where that has become an occupational disease and who, to use the apt Americanism, sticks his neck out to the utmost limit on all matters in which he profoundly believes. Thus I can think of no other mstance of an author not only making his own detailed personal index, but carrying his argument over into it. ${ }^{16}$ Further, the book contains many an extensive deduction or

14 Swisher, Evolution of a Document, 36 Saturday Review, No. 14, at 33, 34 (Apr. 4, 1953).

${ }_{15}$ Thus a pertinent brief summary has just appeared in Judge Spencer Roane of Virginia: Champion of States' Rights-Foe of John Marshall, 66 Harv. L. Rev. 1242 (1953).

16 Consider, for example, p. 1396: "Jefferson, Thomas: admits payments of money to J. T. Callender, 780; admits truth of Walker charge, 779-80; as advocate of general national legislative authority, in 1775,1787 , and $1788,212,764$ note; . . . approves Connecticut libel prosecutions, 773 ; attempt of, to seduce friend's wife, $779 ;.$. . deceptive account of Connect- 
assumption advanced boldly to fill gaps in factual material and to supply motivations. This is the kind of book it is; and, even though I would have toned down some of the truculence, I find something attractive in the forthrightness of the slashing attack. I can foresee that scholars will fall on many of the assumptions with delight, and will demolish at least soine. But, except for surface reactions, that cannot demohsh the book itself or refute the author's central ideas. Crosskey may not have succeeded in getting himself liked; but he cannot be ignored. After this no book on constitutional history or ineaning can afford to overlook his researches.

Hence this is glorious material for the professional historian, be his sympathies for or agamst the thesis presented. But I suggest it is much more than this; it is in fact a must for lawyers, political scientists, and plain ordinary citizens. For it brings up insistently the issue of the kind of government needed not merely for 1787 , but also for 1953 . I realize that the first reaction to the author's argument by the lay reader is likely to be: So what? After all, the Court responding to pressures over a century and a half has construed the Constitution as it has; and the people have surely accepted the result, nay, are belligerent against any (outward) change. So it will be said: Let's leave to the students these faraway battles, while we go about our busmess of returning just as much power to the states as the pressure of world and local events will permit. The trouble is, however, that the militant advocates of the status quo have been able to seize an advantage which is not rightfully theirs. They have claimed all the support of the sacred document itself to use agamst those upstarts who assert a national power as a matter of right and necessity. Against such a heavy burden the forces of centralized efficiency can inake only difficult headway without vicarious support froin those twin forces of evil, to wit, war or depression. Except when those forces make the need overwhelming, we must be bound to a government the more mactive, i.e., the more unobtrusive, the better. American genius can be expended to perfecting the automobile, discovering new labor devices for farm, factory, and home and uncovering the atom bomb. Only in matters goverumental must it remain bound by chains of the past.

So the great function of a book such as this is to show that these chains are hardly real and, in any event, are comparatively recent and inan-

icut libel prosecutions by, in 1809,784 note; disloyalty of, to Washington, whilst in his cabinet, 767; duplicity of, on freedoin of press, 767-84; . . . orders dismissal of Connecticut libel prosecutions upon learning what they concern, 781," etc. Also p. 1393: "Frankfurter, Felix: on Constitution as ultimate touchstone, 318, 906; on Constitution as not ultimate touchstone, 318," etc. 
made, to be unmade in like fashion if the will exists. In short, the purpose of history is to free man from the shackles of pseudo-history. We should be masters of our fate governmentally as much as physically, institutionwise as much as gadget-wise. And the days of planned experimentation in new ways of living together should definitely not be over. For if we do not take active measures with intelligent effort, the change is going to take place in any event imperceptibly and in ways we not only may not expect, but certainly do not want. Sucl a book as this teaches overwhelmingly that change is coming in any event, no matter how unchanging may seem our governmental charter and its basic exposition.

That leads me to what $I$ consider a wholly fascinating example of this process, both because of its recent operation before our very eyes and because of its far-reaching consequences. This is what I have chosen elsewhere to term the "brooding omnipresence" of the Erie-Tompkins case.17 That decision, as every lawyer knows, in 1938 overruled more than a century of precedents to require federal courts to show the most complete subservience to substantive state decisions in all issues touching state law coming before them.

It might be expected that Professor Crosskey's wide-ranging and iconoclastic imvestigations would dredge up new thoughts and new approaches to this controversial subject. So he does, with incidental attacks on the state of legal scholarship which permitted one historical article to have so profound an effect on reversing previous trends, and with a rehabilitation of the greatness of Justice Story, who had come to be viewed as a vain little man with only the most naive of conceptions as to the nature of law itself. The exposition details, in fact, three major stages of development, of which the overruled Swift $v . T y s o n^{18}$ represented not the original, but a halfway or intermediate, step toward the state supremacy we now have. So let us follow our author back to the Constitution and his view of "The National Judicial Powers under an Eighteenth-Century Interpretation" of the document, which makes natural "the Supreme Court's Judicial Supremacy and the Common-Law Jurisdiction of the Courts of the Umited States." 19

\footnotetext{
${ }^{17}$ Erie Railroad Co. v. Tompkins, 304 U.S. 64 (1938). See Clark, State Law in the Federa] Courts: The Brooding Omnipresence of Erie v. Tompkins, 55 Yale L.J. 267 (1946). Compare Mr. Justice Holmes dissenting in Southern P. Co. v. Jensen, 244 U.S. 205, 222 (1917): "The common law is not a brooding omnipresence in the sky but the articulate voice of some sovereign or quasi sovereign that can be identified"-a critique of law accepted as the base of the Erie decision. See Guaranty Trust Co. v. York, 326 U.S. 99, 101; 102 (1945).

1816 Pet. (U.S.) 1 (1842).

${ }^{19}$ C. XX, pp. 610-40.
} 
We need not repeat here the process of interpretation outlined above, but proceed at once to the conclusion, which is that indicated by the chapter heading just quoted. The inost important for our immediate purposes are the Supreme Court's stewardship of the entire court system of the nation and the acceptance for the federal courts of the existence of a national common law, that being the common law of the mother country, England. The demonstration is too long to give in detail; it follows quite naturally from the supremacy over state laws or constitutions to be accorded to the "laws of the United States which shall be made in Pursuance" of, i.e., under, the Constitution, with the law-1naking power construed as broadly as is stated above.$^{20}$ But the initial interpretation itself is interesting, indeed fascinating. ${ }^{21}$ Thus it involves acceptance by the early leaders of a common law of crimes, involving criminal libel invoked at Jefferson's behest against, among others, a Connecticut clergyman, Azel Backus. But most striking in view of later doctrine is a now overlooked decision by the Supreme Court in 1805, Marshall writing, where the Court assumed without hesitation to declare a question of state local land law contrary to the view of the state courts. The case is Huidekoper's Lessee v. Douglass, ${ }^{22}$ where the Court construed a Pennsylvamia statute of 1792 defining grants of the state's vacant lands in the West Allegheny or northwest area of the state to uphold, as against the state, conveyances to a land company, contrary to the holding of the state supreme court four years earlier in Commonwealth of Pennsylvania v. Coxe. ${ }^{23}$ The author's thoroughness appears particularly in colmection with this case; to show its initial wholehearted acceptance, the later trend toward evasion of its principle, and the final acceptance of its consequence, with some demurring by the state, he has apparently examined all records-official, newspaper, and otherwise, together witl local correspondence of public officials and judges as disclosed by the local offices and historical societies of the region. ${ }^{24}$ The inportance of the case is clear. Here was the natural supremacy of the Court accepted without question in an area now termed the "clearest kind" of case for application of the Erie-Tompkins doctrine of state law supremacy. ${ }^{25}$

${ }^{20}$ See pp. 984-1002 construing the Supremacy Clause, U.S. Const. Art. 6.

${ }^{21}$ C. XXIII, The Initial Recognition of the Supreme Court's Position as the Nation's Juridical Head, pp. 711-53.

23 Cranch (U.S.) 1 (1805).

${ }^{23} 4$ Dall. (U.S.) 170 (1801).

${ }^{24}$ Pp. 719-53.

2s The expression is taken from the recent case of Waterhouse v. Hoover, 203 F. 2d 171 (C.A. 6th, 1953). 
But all this was soon to change. A chapter which describes the "Loss of the Common-Law Jurisdiction" of the national judiciary begins thus:

Among the causes of the Supreme Court's decline as the nation's juridical head, which began in the 1820's, first place must be given to the original national Judiciary Act of 1789, which the First Congress under the Constitution enacted. For there were in that act at least two features that operated powerfully to postpone and, in the end, defeat the great judicial reform which the framers of the Constitution intended. The first of these was the Supreme Court's great remoteness, under the act, from the trial courts of the states; the second was the relative inaccessibility of the national trial courts which the act set up, as compared with the similar state tribunals. ${ }^{26}$

Soon Marshall himself was conceding the decline, ${ }_{; 7}^{27}$ and there came the rise of another principle, that of the "Theory of Two Independent Judiciaries without a Common Head." ${ }^{28}$ The situation is perfectly illustrated in 1842, after Marshall's death, by the celebrated case of Swift $v$. Tyson, ${ }^{20}$ written by Justice Story, the semor member of the Court in service. That decision involved an aspect of general commercial law-whether a preexisting debt owed by the endorser to the endorsee of a bill of exchange was sucl consideration as would render the bill "negotiable" to cut off defenses good between the original parties. There being some question whether New York law on this issue might be different from that accepted in the federal courts, Story assumed only to declare a federal or general law applicable in commercial matters of wide extent and ramification in businesses naturally transcending state laws. Although this has latterly been viewed as a bold and arrogant assumption of power, it was actually modest indeed. Our author regards it as part of that rear guard action to which Marshall himself lad been forced in an endeavor to save some vestiges of national power. Certainly the precedents of the time show it far from a rash innovation. ${ }^{30}$

It is this case which brought forth the scorn of judges and writers until at length it was suddenly overruled and even declared unconstitutional by a divided court without argument on the point. The latter is of course the famous Erie R. Co. v. Tompkins, ${ }^{31}$ undoubtedly the most cited judicial precedent of modern times. ${ }^{32}$ The decision was dedicated to the establish-

${ }^{28} \mathrm{C} . \mathrm{XXXV}, \mathrm{p} .754$.

${ }^{27}$ Note, for example, such a case as Green v. Neal's Lessee, 6 Pet. (U.S.) 291 (1832), while Marshall was still on the Court.

${ }^{23}$ C. XXV, pp. 818-64.

2916 Pet. (U.S.) 1 (1842).

${ }^{30}$ See extensive discussion, p. 856 et seq.

- 31304 U.S. 64 (1938); see note 17 supra.

32 Indeed, frequency of citation seems on the increase. Shepard's United States Citations contains less than 8 full columns of citations of the decision in the original volume to 1943, but the 1943-52 Supplement contains 16 columns, and the July, 1953, pamphlet, 3 columns. 
ment of an exceedingly simple and appealing principle. But its mandate has proven quite as confusing and complex in its application. The simple proposition is that litigants should not be subject to one law in one court and a different law in another court in situations otherwise identical. And the complexity arises from the attempt to carry out this view where not one government but forty-nine separate sovereignties, with varying rules of law, are assumed to be supreme, or at least are owed obeisance.

It is possible, and Professor Crosskey's researches tend to show, that such a division of power as was contemplated under the Sreift v. Tyson rule and such a two-headed system could never continue and that eventually one branch must prove the stronger and more dominant. The present writer has believed the contrary, ${ }^{33}$ thinking that the approach best defined in decisions of Justice Cardozo $0^{34}$ of "a benign and prudent comity" whereby the federal courts would accept state principles where really apposite, but would not be forced to rigorous and arbitrary extremes im so doing, presented a flexible and a working solution to a difficult problem hardly susceptible of resolution solely into blacks and whites..$^{35}$ But events seem to prove otherwise. There were cases showing an unattractive jockeying for position in the federal courts to get away from state litigation. AIthough these, as Crosskey points out, were capable of other solutions, ${ }^{36}$ they opened the way. for strong arguments as to the unfairness of the then existing rule as applied to the "diversity" cases, i.e., those which would have arisen in the state courts except for the accident that the parties were citizens of different states and hence entitled to a federal forum under the Constitution. Such arguments were helped by an article by the major historian of the Court showing discovery of an early draft of the First Judiciary Act which contained an inclusive neaning of what became "the laws of the several states" in the famous Section 34 of this

The 1953 Cumulative Annual Pocket Part to 22 Fed. Dig. has 81 pages of direct rulings, $\$ 8359-62$, as against 23 pages in the original volume of 1940 .

${ }^{33}$ And so stated in the article cited note 17 supra, referring to the decisions in note 34 infra.

34 Mutual Life Ins. Co. of N.Y. v. Johnson, 293 U.S. 335, 339 (1934); Hawks v. Hamill, 288 U.S. 52 (1933); Marine Nat. Exchange Bk. of Milwaukee v. Kalt-Zimmers Mfg. Co., 293
U.S. 357 (1934).

${ }^{35}$ No pun is intended with respect to the famous case cited note 36 infra, which did so much to provoke the Erie-Tompkins doctrine.

${ }^{36}$ Thus, the notorious Black \& White Taxicab \& Transfer Co. v. Brown \& Yellow Taxicab \& Transfer Co., 276 U.S. 518 (1928), allowing a corporation to escape state law by dissolving in the original state and reincorporating elsewhere to become a "diverse" citizen of its original own state, rested upon a much criticized fiction as to corporate citizenship. See McGovney, A Supreme Court Fiction, 56 Harv. L. Rev. 853, 1090, 1225 (1943). 
Act. ${ }^{37}$ But Crosskey does not find this newly discovered document surprising, or as compelling of the one single conclusion of complete federal subordination as the Court assumed; and he is particularly scornful of the low state of legal scholarship which failed to point this out. ${ }^{38}$ At any rate the Court, albeit by a narrow majority, made the sharp turn toward rigid conformity with state law and has since enforced it relentlessly as a general principle, although with somewhat surprising variations of detail.

Fifteen years of steady litigation to determine the ineaning of ErieTompkins have left a toll of still further need for litigation, with many areas unsettled. ${ }^{39}$ There has been in soine respects expansion, in soine respects limitation, frown what seemed to be the doctrine as first announced. The limitation has been in the area of federal rights and federal specialties; a government-issued check has rather surprisingly been held not subject to state commercial law, ${ }^{40}$ while bankruptcy, copyright, and now perhaps trademarks have been held in varying degrees subject to a federal uniform law. ${ }^{41}$ On the other hand, the most troublesome expansion

${ }^{37}$ Warren, New Light on the History of the Federal Judiciary Act of 1789, 37 Harv. I. Rev. 49 (1923).

18 Pp. 626-28, 820, 857-59, 866-937, 1170, 1171.

s8 Both the case law and the legal literature are so extensive, and so constantly expanding, as to defy citation here. Even the critical titles of some of the articles are interesting: Keeffe, Gilhooley, Bailey and Day, Weary Erie, 34 Corn. L: Q. 494 (1949); Harnett \& Thornton, Precedent in the Eerie-Tompkins Manner: A Decade in Retrospect, 24 N.Y.U.L.Q. Rev. 770 (1949); Merrigan, Erie to York to Ragan-A Triple Play on the Federal Rules, 3 Vand. L. Rev. 711 (1950); Gavit, States' Rights and Federal Procedure, 25 Ind. L.J. 1 (1949), 21 Okla. B.A.J. 619 (1950). There has also been some recent notable support to the effect that the Erie doctrine is neither so objectionable nor so extensive as the other authors have concluded. Parker, Erie v. Tompkins in Retrospect: An Analysis of its Proper Area and Limits, 35 A.B.A.J. 19 (1949); Moore's Commentary on the U.S. Judicial Code 320, 359 (1949). My article, cited note 17 supra, contains references to existing authority to its date; later references have been added to a forthcoming reprinting of the essay in a book of legal essays sponsored by the Association of the Bar of the City of New York. The articles and cases cited below are only a fraction of those available, but may be taken as illustrative of the deluge now inundating the federal courts.

${ }^{10}$ Clearfield Trust Co. v. United States, 318 U.S. 363, 744 (1943). For other examples, see Clark, op. cit. supra note 17, at 284, 285. See also Phelan v. Middle States Oil Corp., 154 F. 2d 978, 1000-1002 (C.A. 2d, 1946), noted in 59 Harv. L. Rev. 1286 (1946); United States v. Standard Oil Co. of Cal., 332 U.S. 301 (1947), and Francis v. Southern P. Co., 333 U.S. 445 (1948), both extensively discussed in the law reviews; Brown v. Western Ry. of Ala., 338 U.S. 294 (1949); Exceptions to Erie v. Tompkins: The Survival of Federal Common Law, 59 Harv. L. Rev. 966 (1946).

41 There has been, however, considerable conflict as to details. See, e.g., Austrian v. Williams, 198 F. 2d 697 (C.A. 2d, 1952), cert. den. 344 U.S. 909 (1952), extensively criticized in Federal Modification of State Law: Erie and the Bankruptcy Statute of Limitations, 62 Yale L.J. 479 (1953), and discussed in other review notes; Admiral Corp. v. Peuco, Inc., 203 F. 2d 517 (C.A. 2d, 1953); and Dad's Root Beer Co. v. Doc's Beverages, 193 F. 2d 77, 79-82 (C.A. 2d, 1951) compared with Hyde Park Clothes v. Hyde Park Fashions, 204 F. $2 d 223$ (C.A. 2d, 1953), dealing with the law of trademarks and unfair competition; also Stevens, Erie R.R. v. Tompkins and the Uniform General Maritime Law, 64 Harv. L. Rev. 246 (1950); Hill, The Erie Doctrine in Bankruptcy, 66 Harv. L. Rev. 1013 (1953). 
has come in the dichotomy of substance and procedure. The latter, being the adjective law by and under which the courts operate, has admittedly been under the control of the Supreme Court itself; with the adoption of new federal rules of civil procedure by the Court just before announcement of its Tompkins decision, a new era of reformed and simple court action was inaugurated, one widely acclaimed as model for the states and indeed in process of rather extensive adoption in the several states. ${ }^{42}$ But as Crosskey says, "friends of the new rules had to whistle very loudly to keep their courage up, after the York decision." 43 This was a decision in $1945^{44}$ wherein the Court redefined substance to include anything which might substantially affect the outcome of the case, and thus relegated the procedure which is alone subject to federal control to such a narrow compass in the diversity cases as to have no significant scope, as later decisions indicate..$^{45}$ So the present situation as to this cherished court reform is that, as a text writer has cynically, but shrewdly, advised, ${ }^{46}$ a lawyer in these cases had better pursue the more technical form of procedure, state or federal, in his instant situation in order to be safe. And since as a corollary a state enactment or decision depriving a state court of jurisdiction is held to have a like effect on a federal court in a corresponding diversity case, ${ }^{47}$ Professor Crosskey concludes: "So, in the end, even the Supremacy Clause has been rewritten by the Court, in its mad pursuit of its unattainable, unconstitutional Erie object." 48

Two other pressing problems must be stated, though they do not exhaust the possibilities. The first concerns what lawyers call the problem. of the conflict of laws, resulting from the interaction of differing state principles of law. ${ }^{49}$ The original Erie-Tompkins decision merely required

12 Clark, Code Pleading 23-31, 51-54 (2d ed., 1947); Clark, The Federal Rules in State Practice, 23 Rocky Mt. L. Rev. 520 (1951); Millar, Civil Procedure of the Trial Court in Historical Perspective (1952), passim.

${ }^{43}$ P. 1367 , citing my article note 17 supra. He might have added further works of mine, e.g., book reviews in 36 Corn. L. Q. 181, 184 (1950) and 4 Vand. L. Rev. 392, 395 (1951).

44 Guaranty Trust Co. v. York, 326 U.S. 99, 108, 109 (1945).

${ }^{45}$ Woods v. Interstate Realty Co., 337 U.S. 535 (1949); Ragan v. Merchants Transfer \& Warehouse Co., 337 U.S. 530 (1949); Cohen v. Beneficial Indus. Loan Corp., 337 U.S. 541 (1949). Mr. Justice Rutledge dissented in all three cases, 337 U.S. 557. These cases, together with the York and Bullington cases, notes 44,47 , have been the subject of critical comment in the law reviews too extensive to document here.

45ederal Procedure: The "Outcome" Test Applied in Actions Based on Diversity of Citizenship, 35 Corn. L.Q. 420 (1950).

17 Angel v. Bullington, 330 U.S. 183 (1947).

18 P. 933.

19 The type of problem is indicated in Professor Cavers' review in 66 Harv. L. Rev. 1327 (1953) of Marsh, Marital Property in Conflict of Laws. See also such articles as Harper, The Supreme Court and the Conflict of Laws, $47 \mathrm{Col}$. L. Rev. 883 (1947); Wolkin, Conflict of Laws in the Federal Courts: The Erie Era, 94 U. Pa. L. Rev. 293 (1946); Silving, Analogies 
the federal court sitting in New York City to apply the law of Pennsylvania to govern a railroad accident occurring in the latter state; it gave no thought to what law the New York courts might apply to this situation. Later cases have supplied the refinement that the federal court, being for the immediate purpose but another court of the state where it is sitting, must apply the law of that state strictly. ${ }^{50}$ So there is a kind of double separation from the immediate objective in any case which has arisen at a distance from the particular courthouse. The federal judge must try to ascertain what a state court judge would apply as the law of the "foreign" state where the "cause of action" arose. Of course complications increase rapidly when, in our swiftly moving and far-flung commercial civilization, a cause really arises in and concerns not one, but two or many states. But beyond these obvious difficulties of federal orientation in modern busmess life there is the equally obvious opportunity now afforded for playing one court against another, to stop which was the prime reason for the Erie case in the first place. As Crosskey puts it: "Yet it manifestly was a certainty, surely apparent to the Court, that, by its decision, it was creating a new motive for jockeying by litigants, not, it is true, to get into the state court, or the national court, of a particular state, but to get into the national court of whichever of our states may happen to have a conflict-oflaws rule favorable to a particular party's claim or defense." ${ }^{21}$ The result has disclosed adjudications which appear fully as anomalous as, if not more than, anything in the pre-Erie era. In one notable case ${ }^{52}$ a litigant was able by the greater facilities of federal procedure to raise an issue in a Texas federal court which he would not be in a position to reach in the state court, and then to obtain a favorable result by application of a legal principle of the law of insurance recognized in only Texas and Quebec. The question was one of interpleader between citizens of Texas and citizens of New York involving the proceeds of a pohicy of insurance issued by a New Jersey company; the inere fact that the Texas claimants could sue the insurance company in the Texas federal court as a "diverse

Extending and Restricting Federal Jurisdiction; Erie R. Co. v. Tompkins and the Law of Conflict, 31 Iowa L. Rev. 330 (1946); Wolfson, Uniform Law and the Federal Courts Under the Erie Doctrine, 23 Temp. L.Q. 404 (1950).

${ }^{50}$ Klaxon Co. v. Stentor Electric Mfg. Co., 313 U.S. 487 (1941); Griffin v. McCoach, 313 U.S. 498 (1941). Mr. Justice Rutledge in his dissent, note 45 supra, 337 U.S. 557, 560 n. 1, has pointed out this extension of the original doctrine; and see Wells v. Simonds Abrasive Co., 345 U.S. 514 (1953).

${ }^{51}$ Pp. 928, 929.

52 Griffin v. McCoach, 313 U.S. 498 (1941). See New England Mut. Life Ins. Co. v. Spence, 104 F. 2 d 665, 668 (C.A. 2d, 1939). 
citizen" to them, and that the latter then had the benefit of federal interpleader to exonerate it on citing in the New York claimants and paying the money into court, resulted in the non-applicability of the more general rule applied in New York and New Jersey.

The other pressing problem is as to the mere ascertainment of the state law which is thus to be so slavishly applied. On many occasions the state court has not spoken; this is particularly true of problems arising out of state law as to conditional sales, chattel mortgages, trust receipts, but only coming to a head when the parties meet in the federal bankruptcy court. On others only an inferior state court has spoken; though its views may not seem persuasive, yet they have been held controlling. In a notable case the federal courts were directed to follow a state ruling in New Jersey where later the New Jersey courts admitted the cogency of the original federal ruling as a matter of judicial sense and followed it, though "reversed on a different point." 53 Here in a very real sense the federal judges, in spite of all the pains taken to make them so, are unhke their brethren in the corresponding state courts; their role is limited to that of "ventriloquist's dummy"54 as to state law, while their state brethren, even the lowliest of them, may use their best mental and intellectual powers to reach results which satisfy their minds. In consequence where a state doctrine seems fast becoming obsolete, a litigant in the federal courts is at a serious disadvantage; for the state judge may declare the doctrine dead, while the federal judge may not. ${ }^{55}$

We need not accept the most extreme of the Crosskey strictures to find the present situation vastly disturbing. For my part, I must regard it as inore troublesome, over a wider area of confusion, than was the pre-Erie rule, unfair as that occasionally proved to be. And the consequence seems so hard to avoid, so practically inevitable, under our present system of divided or relinquished supremacy. I am indicating some criticism of recent Supreme Court decisions, as I believe is still the right and privilege of all "inferior" judges. But I am bound to add that, however I might change

b3 Fidelity Union Trust Co. v. Field, 311 U.S. 169 (1940), rev'g. Field v. Fidelity Union Trust Co., 108 F. 2d 521 (C.A. 3d, 1939), which was approved and followed on its substantive point in Hickey v. Kahl, 129 N.J. Eq. 233, 19 A. 2d 33 (1941); Lester v. Guenther, 132 N.J. Eq. 496, 28 A. 2d 777 (1942), and other cases cited by Crosskey, p. 1366. For biting criticism of the "unbelievable decision," see Crosskey, pp. 922-27.

64 Frank, J., in Richardson v. C.I.R., 126 F. 2d 562, 567 (C.A. 2d, 1942).

w5 See discussion by Crosskey at 918 et seq., 929 et seq., and by me in 55 Yale L. J. 267, at 290-95 (1946). The point is illustrated by such a case as Newkirk v. C. C. Bradley \& Son, 271 App. Div. 658, 67 N.Y.S. 2d 459 (4th Dept., 1947), repudiating the view of New York law taken as compelled in Droste v. Harry Atlas Sons, 145 F. 2d 899 (C.A. 2d, 1944), 147 F. 2d 675 (C.A. 2d, 1945), cert. dismissed 325 U.S. 891 (1945). 
the individual pieces about, I should arrive at no less or little less jerrybuilt structure than the present process of judicial inclusion and exclusion has produced. Nor are we at the end of all development; it is perfectly clear that the rules are even now shifting as to several details. I anticipate -perhaps as a matter of hope rather than of definite omen-reading-that the trend to minimize the area of procedure will halt, that the scope of federal law will expand, that the conflicts-of-laws problems will be reduced in number and scope. For exaniple, the most recent decision of the Court on the latter problem, rendered this spring, seems to find a considerable number of the justices ready to return to the original Erie conception that Pennsylvania law, rather than New York's conception of Pennsylvania law, should govern. ${ }^{56}$ Some solution will appear, even if we cannot prophesy just what that will be.

Of course it would be simple to turn to Crosskey's solution. "All that would be necessary would be to abandon the unconstitutional Erie case and return to Srevift v. Tyson and Huidekoper's Lessee v. Douglass. For those two cases, with the Supreme Court's Constitutionally granted juridical supremacy added thereto, would bring about order and uniformity in our law." Th7 This is recommended not only for this "the most fundamental and far-reaching error the Supreme Court has ever made," but also for the other "unconstitutional" diminutions of national authority; for "it will not be forgotten it is the Constitution, and not the Supreme Court's accumulated errors about it, which Congress and the Justices take oath 'to support,' and the President swears he will 'preserve, protect, and defend." " B59 Before such a bold spirit and so sublime a confidence I can only bow in admiration. Were the making of the government to be done over, I can hardly believe that it would not be along lines Crosskey advocates as still the true ones. I cannot subscribe to the view that the only way to freedom is via an inefficient and thereby hopelessly weak goverument. I do not beheve man is so little master of his fate that only by putting stones in his way may he be trnsted to walk at all. I believe that an effective government which can be made responsive to the will of its constituents is a necessity for survival. But even so, I cannot see signs that we are yet mature enough to accept the challenge. Yet new threats of war, new depths of depression may in time lead us to a new orientation of purpose and objectives whereby "We, the People of the

${ }^{56}$ Wells v. Simonds Abrasive Co., 345 U.S. 514 (1953).

57 P. 934.

68 P. 1169.

s9 P. vii. 
United States," may act "to form a more perfect Union," to "establish Justice," and to "promote the general Welfare, and secure the Blessings of Liberty to ourselves and our posterity." 60 When that time comes I cannot believe but that devoted attempts such as this to ascertain what was originally purposed and how results fell slort of objectives will play a large part in shaping our heavenly city of the future.

${ }^{60}$ These quotations are from the Preamble to the U.S. Constitution, which of course furnishes a glowing text for the Crosskey sermon. 